\title{
OBITUÁRIO
}

\section{José Júlio da Ponte Filho}

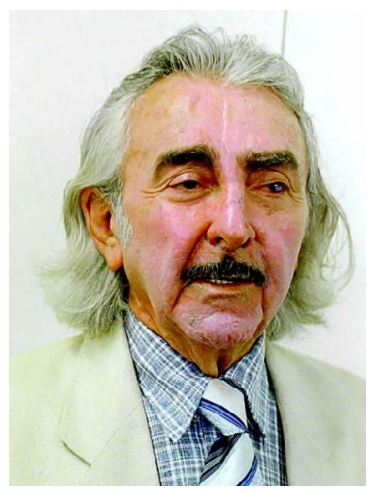

Faleceu no dia 19 de fevereiro, na cidade de Fortaleza, o renomado Professor de Fitopatologia da Universidade Federal do Ceará, José Júlio da Ponte Filho. Após sua aposentadoria, Prof. José Júlio foi agraciado com título de Professor Emérito da UFC, que lhe foi conferido pela contribuição para o crescimento e a consolidação da Universidade. A par de professor de excelente didática, José Júlio destacou-se pela sua abnegação à pesquisa científica. Foi pesquisador, com bolsa de Produtividade Científica do CNPq, Nível 1 A por vários anos, com mais de uma centena de publicações científicas, incluindo artigos e livros na área de Fitopatologia.

Por suas mãos passaram várias gerações de professores da UFC, tendo sido Presidente da Sociedade Brasileira de Fitopatologia, Presidente da Sociedade Brasileira de Nematologia, fundador e Presidente da Academia Cearense de Ciências e Comendador da Ordem Nacional do Mérito Científico por ter se destacado na pesquisa com alternativas naturais aos agrotóxicos, descobrindo que a manipueira, extrato líquido que sobra no processo de fabricação da farinha de mandioca, pode ser aplicado, com sucesso, ao controle de fito nematóides. 